\title{
Bir memorat örneği olarak Cinânî'nin cinleri
}

\section{Osman ÜNLÜ2}

\begin{abstract}
APA: Ünlü, O. (2019). Bir memorat örneği olarak Cinânî’nin cinleri. RumeliDE Dil ve Edebiyat
\end{abstract} Araşttrmaları Dergisi, (Ö6), 229-239. DOI: 10.29000/rumelide.648853

\section{Öz}

XVI. yüzyll Osmanlı edebiyatının önde gelen temsilcilerinden olan Cinânî’nin (öl. 1595) eserlerinden biri de Bedâyiü’l-âsâr'dır. Bir hikâye külliyatı olan bu eser temel olarak kadınlar, savaşlar ve acayip olaylar olmak üzere üç bölümden oluşmaktadır. Eserin acayip olaylardan bahseden bölümünün alt başlıklarından biri de cinlerle ilgili hikâyelerdir. "Tabiatüstü ferdi bir tecrübenin yaşayan veya ondan dinlemiş birisi tarafından anlatılan şahsa bağlı hikâye” olarak tanımlanan memorat teriminin kapsadığı konulardan biri de cinlerle tecrübe edilen olağanüstü olaylardır. Çalışmada, Cinânî’nin Bedâyiü'l-âsâr adlı hikâye külliyatında yer alan cinlerle ilgili 12 hikâyenin memorat terimi kapsamında bir değerlendirmesi yapılmıştır. Bu hikâyelerdeki olayların memorat kapsamında değerlendirilmesi gerektiği sonucuna ulaşılmıştır.

Anahtar kelimeler: Cinânî, Bedâyiü’l-âsâr, memorat, cinler.

\section{Cinânî's stories about jinn as an example of memorate}

\begin{abstract}
One of the works of Cinânî (d. 1595), one of the leading representatives of XVI ${ }^{\text {th }}$ century Ottoman literature, is Bedâyiu'l-âsâr. A collection of stories, this work consists of three parts mainly of women, wars and strange events. One of the subtitles of the part of the work that talks about strange events is stories about the jinn. Memorate is defined as a person-related story told by someone who has lived or listened to a supernatural individual experience. One of the topics covered by the term memorate is the phenomenon experienced with jinn. In this study, an evaluation of 12 stories about jinn in Cinânî's story corpus named Bedâyiu'l-âsâr was made within the context of memorate term. It was concluded that the events in these stories were evaluated within the scope of the memorate.
\end{abstract}

Keywords: Cinânî, Bedâyiu'l-âsâr, memorate, jinn.

Halk edebiyatı anlatı türlerinin arasında yer alan "memorat"ın efsaneden ayrı bir anlatı türü olarak kabul edilmesi diğer türlere göre çok yenidir. Bu terim, İsveçli halkbilimci Carl Wilhelm von Sydow tarafından 1934 yllında ortaya atılmış ve bu tarihten itibaren de halkbilim ve antropoloji dünyasına resmen dâhil olmuştur (Çobanoğlu, 2003: 21; Hallaç, 2018: 183). Kısaca "şahsi tecrübe anlatıları" olan memorat kavramı uzun bir süre bilim dünyasında kabul görmemiştir. Bunun en önemli sebebi şüphesiz aydınlanma ve arkasından gelen modernizmin saf aklı ve akılcılığı temel almasıdır. Ancak denenebilir ve akla uygun olma gayesindeki ampirik bilginin bu tür tecrübe ve olaylarda yetersiz kalacağı

Bu makale, 26-28 Eylül 2019 tarihleri arasında Bandırma Onyedi Eylül Üniversitesinde gerçekleştirilen Uluslararası Filoloji Çalışmaları Konferansında (Internatıonal Conference On Academıc Studıes In Phılology (BICOASP)) aynı adla sunulmuş bildirinin genişletilmiş ve yeniden düzenlenmiş halidir.

2 Doç. Dr., Bandırma Onyedi Eylül Üniversitesi, İnsan ve Toplum Bilimleri Fakültesi, Türk Dili ve Edebiyatı Bölümü (Balıkesir, Türkiye), osm.unlu@hotmail.com, ORCID ID: 00oo-0003-4729-7342 [Makale kayit tarihi: 06.10.2019-kabul tarihi: 20.11.2019; DOI: 10.29000/rumelide.648853] 
muhakkaktır. Dolayısıyla bu bakış açısının hâkim olduğu modern bilim anlayışında "memorat”ın ayrı bir edebiyat türü olarak görülmesi ve kabul edilmesi pek kolay olmamıştır.

Memoratın en önemli özelliği, doğaüstü olmasının yanında anlatıcılar tarafından bizzat yaşanmış olmasıdır. Tecrübe edilmiş ve yaşanmış deneyim olması, memoratı diğer olağanüstü anlatı türleri olan mit, masal ve efsaneden ayırır. Diğer türlerde gerçek hayatla birebir örtüşme veya muhatabı anlatılan şeylere inandırma gayesi veya endişesi yokken memoratlarda bu amaç ön plandadır ve muhatap karşısında bu yön özellikle vurgulanır.

Memorat kavramının ortaya atılmasından günümüze kadar geçen süre içinde bu kavram ve türe ilişkin çeşitli tartışmalar yapılmış ve bu tartışmalar günümüzde de devam etmektedir3. Memoratların diğer türler içinde en fazla benzeştiği tür, efsanelerdir. Bu nedenle birçok halkbilimci tarafından bu iki tür bir arada ele alınmış ve kısmen de ele alınmaya devam etmektedir (Çobanoğlu, 2003: 25). Memoratların aktarımındaki şahıs zincirinin artması sonucu memorat olmaktan çıkıp kurguya dayalı bir anlatım türüne (fabulat) dönüşmesi düşüncesi halkbilimi çevrelerinde kabul edilen görüşlerden biridir (Hallaç, 2018: 196). Bu türler arasındaki en önemli ayrım ise tecrübe sahibinin bilinmesi veya bilinmemesi üzerinedir (Hallaç, 2018: 198). Buna göre bir memoratın yaşayan bir bireyle olan bağı ortadan kaldırıldığında o artık bir memorat değil efsane olarak kabul edilmektedir. Aynı durumun tersi de olabilmektedir. Halk arasında bazı gezgin efsanelerin yaşayan veya yaşamış bir şahsa veya bir yere bağlanarak memorat haline gelmesi de ihtimal dışı değildir. Bu tür memoratlar "sözde memorat" olarak adlandırılmaktadır (Çobanoğlu, 2003: 17). Ters ayaklı cinlerin yurtlarda sık sık anlatılması bu ikinci türe iyi bir örnek sayılabilir (Çobanoğlu, 2003: 26-31; Sevindik-Yaman, 2018: 387-394).

Bu hususu aynı olayı anlatan iki metin üzerinde örneklemek yerinde olacaktır. İlk örnek bir efsane metnidir. Burada olayın yaşandığı yer ve olayı yaşayan insanların kimliği belirsiz ve anonimdir, herhangi bir yer ve herhangi bir kişi olabilir:

Bir öğrenci, yatılı okulda okurken bir gece tuvalete kalkar. Yatakhane koğuşunda herkes uyumaktadır. Koridorun karşısındaki tuvaletin kapısını açar. Karşısında yatakhane arkadaşlarını görür. Yanlarına yaklaşınca hepsinin ayaklarının ters olduğunu görür. Can havliyle kendini dışarı atar. Güvenlik görevlisine gidip arkadaşlarının hepsinin ayaklarının ters olduğunu söyler. Güvenlik görevlisi de ayağa kalkıp ayaklarını göstererek “Böyle mi?” der. O öğrenci bir anda düşüp bayılır.

Aynı olayı anlatan hatta yaşayan birinin olayın yaşandığı mekânı ve yaşayan kişilerin de adları zikredilerek aktarıldığında bu anlatı bir efsane değil bir memorat olmaktadır:

Ben Zile'de yatılı imam-hatip okulunda okuyordum. Bir gece tuvalete kalktım. Yatakhane koğuşunda herkes uyuyordu. Koridorun karşısındaki tuvaletin kapısını açtığımda karşımda yatakhane arkadaşlarımı gördüm. Çok şaşırmıştım, yanlarına yaklaşınca hepsinin ayakları tersti. Can havli kendimi dışarı attım. Güvenlik görevlisi İhsan ağabeye hepsinin ayakları ters dedim. O da ayağa kalkıp ayaklarını göstererek "Böyle mi?” dedi. Bir anda düşüp bayılmışım, hala tedavi görüyorum (Sevindik-Yaman, 2018: 390).

Memorat türünün genel olarak sözlü edebiyat ürünü olarak kabul edilmesi, onun günümüzle sınırlandığı düşüncesini doğurmuştur. Örneğin Hartmann'a göre bir anlatı "ben” formunda ise o anlatının günümüze ait olması kaçınılmazdır (Hallaç, 2018: 200). Ancak bunun tam tersine Bennet, memoratın hem günümüze ait hem de antik bir metinden elde edilmesinde herhangi bir sakınca görmemektedir. Reimund Kvideland ise eski eserleri, yazmaları, biyografi ve otobiyografi metinlerini memoratların

3 Bu tartışmalar için bkz. (Hallaç, 2018: 181-211). 
kaynakları arasında zikretmektedir (Hallaç, 2018: 201). Bu ifadelerden yola çıkılarak geçmiş yüzyıllarda kaleme alınmış metinlerde pekâlâ memorat örneklerine rastlanabilir.

Türk halk kültüründe en fazla memorat örneği olan anlatılar cinler hakkındadır demek yanlış bir hüküm olmaz. Cin kavramı sadece Türkler arasında değil dünyanın birçok kültüründe bulunmaktadır. Cinlerin hem inanç hem de kültür açısından önemli bir yere sahip olduğu muhakkaktır. Cinlerin metafizik varlıklar olması nedeniyle onlarla ilgili kültür ve anlatı geleneğinde yaşayan inanışlar bu anlamda en önemli memorat kaynakları arasında yer almaktadır. Özkul Çobanoğlu’nun memorat tasnifindeki 60 tip arasında cinlere ait olanların sayısı 14'tür. Bütün memorat tipleri için derlenen memorat sayısına bakıldığında derlenen 407 memoratın 107'si yani yaklaşık \%26'sı cinlere ait memoratlardır. Bu, memorat açısından cinlerle ilgili anlatıların ne kadar zengin bir kaynak olduğunu göstermektedir.

Cinlerle ilgili inanışların yazılı kaynaklarının eski Mezopotamya medeniyetlerine kadar takip edilebildiğine göre (Beyaz, 2018: 19) Türk kültüründe de bu inancın izleri sürülebilir. Sözlü kültürdeki efsane, destan vb türlerin yanı sıra yazılı edebî ürünlerde de memorat örneklerine rastlanabilmektedir. Bu metinler sayesinde memorat tiplerinin tarih içindeki gelişim ve değişim süreçlerini de bir ölçüde takip etmek mümkün olmaktadır.

Memoratların yer aldığı tarihî metinlerden biri de 16. yüzyılın edebî şahsiyetlerinden biri olan Cinânî (öl. 1595)'nin Bedâyiü'l-âsâr adlı hikâye külliyatıdır. Bu yüzyılın son yıllarında tertip edilerek dönemin padişahı III. Murad'a sunulan eserde yer alan hikâyelerin bir kısmı memorat tanımına uyan ve cinlerle ilgili hikâyelerdir. Eserde toplam 79 hikâye ve 20 de daha küçük boyutta latife olarak adlandırılan metin bulunmaktadır. Bu hikâyelerden 12'si ve latifelerden 4 tanesi doğrudan cinleri konu alır.

Bu hikâyelerin memorat olarak değerlendirilmesi için en önemli kriter, olayı yaşamış olanlardan bizzat veya onun anlattı̆̆ı belli bir kişiden nakledilmiş olmasıdır (Çobanoğlu, 2003: 26; Hallaç, 2018: 197). Bu konuya girmeden önce konuyla alakalı birkaç hususa temas etmek gerekir. Klasik hikâyelerin "râviler şöyle rivayet eder ki ...” ve benzeri belli bir kalıpla başlaması bir gelenektir. Böylece okur veya dinleyici kendini bir kurguya hazırlar. Ancak telif ve yerli hikâyelerde bu durum kısmen farklılaşmaktadır. Yazar, hikâyenin gerçek hayatla ilgisini ve yaşanmış olduğunu vurgulamaktadır (Ünlü, 2017: 271). Cinânî, eserinde bu hususa özellikle dikkat etmiş ve hikâyelerin yaşanmışlı̆ına özenle vurguda bulunmuştur. Konumuz olan hikâyelerin başlangıçlarında yer alan kalıp ifadeler şu şekildedir4.

\begin{tabular}{|l|l|}
\hline $\begin{array}{l}\text { Hikâye } \\
\text { No }\end{array}$ & Hikâyenin Başlangıç Kalıbı \\
\hline 16 & $\begin{array}{l}\text { (Bursa'da) mütevattın olan erbâb-ı hırefden Hâcı Murâd nâm kimesne hakîre böyle rivâyet eyledi ki } \\
\text {... }\end{array}$ \\
\hline 17 & $\begin{array}{l}\text { Yine mahrûsa-i Brusada vâki' olan câmi'-i kebîrde zamânla mü'ezzin olan Karakaş nâm kimesne ki } \\
\text { semtinde nazîri yok bir merd-i 'ârif ve ahvâl-i cihâna mû-be-mû vâkıf idi. Böyle rivâyet eder ki... }\end{array}$ \\
\hline 18 & 'Asker-i İslâm-ı zafer-encâm tâ'ifesinden bir merd-i sipâhî böyle rivâyet eder ki ... \\
\hline 19 & $\begin{array}{l}\text { Yine mahrûsa-i Brusa ahâlîsinden Hasan Dede nâm kimesne bu fakîr-i kesîrü't-taksîre böyle rivâyet } \\
\text { eder ki ... }\end{array}$ \\
\hline 20 & $\begin{array}{l}\text { Bundan akdem Kütâhiyede mütemekkin olup 'izz u tezkîr ile mevsûf ve Firâkî demekle mülakkab } \\
\text { u ma 'rûf olan bir merd-i cihân-dîde vü 'ârifden bu vechile rivâyet ü hikâyet olnnur ki ... }\end{array}$ \\
\hline
\end{tabular}

4 Tablodaki sıra numaraları metnin neşrindeki hikâye numaralarıdır. A harfi ile başlayanlar ise eserin sonundaki anekdotların sıra numarasıdır. Bu metinlerin özetleri çalışma sonunda ek olarak verilmiştir. 


\begin{tabular}{|c|c|}
\hline 25 & $\begin{array}{l}\text { Kużât-ı memâlik-i mahmiyeden birisi bir gün yârân u ihvânla musâhabet ederken ittifâk musâhabet } \\
\text { ol mahalle varur ki ... }\end{array}$ \\
\hline 26 & $\begin{array}{l}\text { Kasaba-i Ankaradan ki 'avâm arasında Engüri demekle meşhûrdur. Kavline i 'timâd olınur bir imâm } \\
\text { böyle rivâyet eyler ki ... }\end{array}$ \\
\hline 28 & Rivâyet olınur ki zamân-ı kadîmde şehr-i Ahmimde iki karındaşlar var imiş ki ... \\
\hline 48 & $\begin{array}{l}\text { Mazhar-ı lutf-ı samedânî merhûm Mevlânâ Gürânî Efendi evlâdından bir kâdî-i nîk-sîret ki hâlâ } \\
\text { vâsıl-ı 'âlem-i 'âhiret olmışdur. Bu fakîr-i hakîre böyle nakl eyler ki ... }\end{array}$ \\
\hline 53 & Yârân-ı kadîm ve dostân-ı hamîmden biri bir tarîkla rivâyet ü hikâyet eyler ki ... \\
\hline 54 & $\begin{array}{l}\text { Mahrûsa-i Brusada merhûm Sultân Murâd Hân-ı Gâzî ‘aleyhi'r-rahme ve’r-rıḍân câmi '-i şerîfinde } \\
\text { mü' ezżin olan Kadrî nâm kimesne bu hakîr-i kesîrü’t-taksîre böyle rivâyet eder ki ... }\end{array}$ \\
\hline 57 & Zümre-i akâribden birisi bu hakîre böyle rivâyet eder ki ... \\
\hline A.17 & $\begin{array}{l}\text { Ahmed Çavuş nâm kimesne nakl eder ki: Arnavud vilâyetinde Dıraç demekle ma rûf olan kal'ada } \\
\text { eger kâfir eger müselmân kaçan ki muhkem hasta olup 'aklı başından gitse ... }\end{array}$ \\
\hline A.18 & $\begin{array}{l}\text { Merhûm Çivi-zâde Efendinüñ mülâzımlarından fârĭg olup dervîş olan Mevlânâ Halîl nâm kimesne } \\
\text { bu hakîre böyle rivâyet eder ki ... }\end{array}$ \\
\hline A.19 & $\begin{array}{l}\text { Bu zamânda Mora diyârına kâdî olan kuzât-ı 'âdileden Mevlâna Seyyid Muhyiddîn nâm kimesne } \\
\text { böyle nakl eylemişdür ki ... }\end{array}$ \\
\hline A. 20 & $\begin{array}{l}\text { Merhûm ve mağfûrun leh Monla Efendi mülâzımlarından olup Sanduklı cânibinde olan Mevlânâ } \\
\text { Recâyî nâm kimesne bu fakîre böyle rivâyet eder ki ... }\end{array}$ \\
\hline
\end{tabular}

Hikâyelerin başlangıçlarına ve anlatıcı kişilere bakıldığında şu tablo ortaya çıkmaktadır. Cinânî̀nin aktardığı hikâyeler biri dışında (28) hepsi de Cinânı̂’nin etrafında olan insanlardan bizzat dinlediği olaylardan oluşmaktadır. Bazılarında anlatıcıların ismi belirtilirken bazılarında ise olayın yaşanmışlığına ve gerçek olduğuna vurgu yapan ifadeler kullanılmıştır. Hikâyelerin ikisinde üçüncü şahıslarla ilgili olaylar (53 ve A17) anlatılırken kalan 13 hikâyede anlatıcı birinci şahıstır. Dolayısıyla eserde yer alan ve cinleri konu edinen 16 hikâyeden 15’i (28 hariç) memorat tanımına uymaktadır.

Burada akla gelebilecek bir husus, bu hikâyelerin anlatıcıdan sonra yeniden yazımı sonrası memorat özelliğinin kaybolup kaybolmadığıdır. Bu konuda, memoratlarla ilgili önemi çalışmalar yapan Reimund Kvideland'ın eski eserleri, yazmaları, biyografi ve otobiyografi metinlerini memoratların kaynakları arasında saydığını (Hallaç, 2018: 201) göz önünde bulundurduğumuzda Bedâyiü'l-âsâr'ın bir memorat kaynağı olarak değerlendirilmesi uygun olacaktır. Hallaç da bu konuda Kvideland'ın fikirlerine katılmaktadır.

Özkul Çobanoğlu, memoratlarla ilgili olarak Türkiye'de yapılan ilk ve şimdilik en kapsamlı çalışma olan eserinde cinlerle ilgili 14 ayrı memorat tipi tespit etmiştir (Çobanoğlu, 2003: 77-78). Buna göre tespit edilen cin memorat tipleri şunlardır:

1. Cinlerin elleri ve ayakları terstir.

2. Cinler çeşitli hayvan şekillerinde görünebilir

3. Küçük ve garip şekilli insancıklar şeklinde görünürler

4. Görünmezler ama davul zurna sesi duyulur.

5. Tanıdık biri şeklinde görünüp uçurum kenarına götürürler.

6. Tanıdıkları biri şeklinde görünüp konuşurlar.

7. Kızdıklarını çarparlar veya başa bir şekilde cezalandırırlar.

8. Evlerde veya tenha yerlerde oyun oynarlar.

9. Cinlerce sahiplenilmiş yerler vardır ve oraya gelenleri cezalandırırlar.

10. İnsanları seçip onlarla evlenirler. 
11. Çıplak veya giyinmiş güzel kızlar şeklinde görünürler.

12. Evlere, camilere girerek insanları korkuturlar.

13. Zorda kalınca insanlardan yardım isterler, karşılığında da ödül verirler.

14. Büyü yapmak veya bozmak için cinler kullanılır.

Çobanoğlu'nun tespit ettiği bu 14 cin memoratından 9'unun Bedâyiü'l-âsâr'da yer alan hikâyelerde de bulunduğu tespit edilmiştir. Buna göre Bedâyiü'l-âsâr'daki hikâyelerde tespit edilen cin memoratı örnekleri şu şekilde gösterilebilir.

\section{Cinler çeşitli hayvan şekillerinde görünebilir}

18. hikâyede bir sipahi Trabzon'da yolda giderken bir köpek yavrusu görür. Daha sonra bu köpek kaybolur, ardından minare boyunda bir adam görür.

19. hikâyede Hasan Dede dere kenarında büyükçe bir kurbağa görür, gece o kurbağanın aslında şekil değiştirmiş bir cin olduğu anlaşılır.

28. hikâyede bahçesine gece vakti giden biri küçük bir köpek görür ve köpeğe ip bağlayıp yanında götürürken onun birden kocaman bir çoban köpeğine dönüştügünü görür.

48. hikâyede bir cin yılan şekline girerek bir delikanlının bacağına dolanır.

53. hikâyede Başmakçı Hasan ile dostu olan cin, ikisi sohbet ederken başka canlıların şekillerine girebildiğini göstermek için yılan şekline girer.

\section{Küçük ve garip şekilli insancıklar şeklinde görünürler}

57. hikâyede hamamı işleten adam 12-13 civarında küçük adamın hamama girdiğini görür. Bunların cin olduğu ise sonradan anlaşılır.

\section{Tanıdık biri şeklinde görünüp uçurum kenarına götürürler.}

54. hikâyede sevdiği kızın şekline giren cin delikanlıyı uçurumun kenarına götürür.

\section{Tanıdıkları biri şeklinde görünüp konuşurlar.}

16. hikâyede cinler Hacı Murat'a, arkadaşları Hacı Ahmet, Tellak Mahmut, caminin fenercisi ve iş ortağı Bekir şeklinde görünerek onunla alay ederler.

54. hikâyede bir cin, bir delikanlının sevdiği kızın şekline girerek onunla ilişkiye girer.

\section{Kızdıklarını çarparlar veya başa bir şekilde cezalandırırlar.}

19. hikâyede cinler, yol kenarında gördüğü kurbağanın gözünü çıkaran Hasan Dede’yi cezalandırmaya çalışırlar.

48. hikâyede yılan şeklindeyken akrabalarının yaraladığı cin delikanlıyı öldürmeye çalışır.

\section{Cinlerce sahiplenilmiş yerler vardır ve oraya gelenleri cezalandırırlar.}


25. hikâyede cinler bir eskicinin bahçesini sahiplenip eskiciyi kaçırmak için evini taşlarlar. Eskici evden çlkmayınca komşu evleri de taşlarlar.

26. hikâyede Ankara'da Karaoğlan çarşısını bir cin kızı tutar ve birçok kişi onu görür.

\section{0. İnsanları seçip onlarla evlenirler}

54. hikâyede bir kadın cin, bir delikanlının sevgilisinin yerine geçerek onunla ilişkiye girer, evlenerek onu sahiplenir.

\section{1. Çıplak veya giyinmiş güzel kzzlar şeklinde görünürler.}

26. hikâyede Ankara'da Karaoğlan çarşısını tutan cin güzel bir kız şeklinde oradakilere görünür.

\section{Evlere, camilere girerek insanları korkuturlar.}

Cinler 16, 18 ve 28. hikâyelerde çeşitli şekil ve kılıklara girerek insanlarla alay eder ve onları korkuturlar.

25. hikâyede eskiciyi evinden kaçırmak için onun evine ve daha sonra komşuların evlerine taş atarlar.

Bedâyiü'l-âsâr'da Özkul Çobanoğlu'nun tespit ettiği memorat tip listesinde yer almayan bir motif daha bulunmaktadır. Eserin sonundaki acibe ve garibe bölümünün son dört rivayetin konusu, ölü veya diri bir bedene cin girmesi, bu cinlerin bedenden çıkarılmasıdır. Bu motif aslında günümüzde de canlılığını devam ettiren bir inanış olduğu için cin memorat tiplerinin arasında yer alması gerektiği düşünülmektedir.

Bundan 400 yllı aşkın bir süre önce kaleme alınmış bir metindeki cin memoratlarının günümüzde derlenen memorat örnekleriyle büyük ölçüde benzerliği dikkat çekmektedir. Aradan geçen uzun zamana rağmen bu kültür kodlarında çok fazla değişimin olmaması dikkat çekicidir. Mesela 19. hikâyede olayın kahramanı yol kenarında gördüğ̈̈ bir kurbağaya taş atarak onu yaralar. O günün gecesinde evine insan şeklinde cinler gelerek taş attığı kurbağanın aslında bir cin olduğunu söylerler. Sonrasında istediklerini yaptırmak için çok uğraşsalar da başaramazlar. Tarih içinde bu bilgilerin izini sürdük. Burada Hasan Dede'nin kurbağaya taş attığı yer olan Eşekyedi mevkii, günümüzdeki Osmangazi'ye bağlı Soğanlı köyünde bulunan bir mevkidir. Köyün güneybatısında Sırameşeler Ormanlar mevkiindedir. Hasan Dede'nin hocası da Muradiye Camii imamı olduğuna göre evi de o civarda olmalıdır. Bu iki mevki arasında yaklaşık 3-4 km mesafe bulunmaktadır. Ülfez adlı yer hakkında ise herhangi bir bilgiye ulaşılamamıştır.

Özkul Çobanoğlu'nun çalışmasında cinlerin kurbağa şekline girmesi memorat tipine ait iki örnek bulunmaktadır. İlkinde romatizma hastası Ahmet Dural derdine bir türlü şifa bulamaz. Sonunda ona nefesi kuvvetli bir hocayı (Enver Hoca) tavsiye ederler. O da bir leğen suyun içine baktırır. Sudan, bir kurbağayı tutup bacağını ezdiğini görür. Ahmet Dural olayı hatırlar. Enver Hoca onun bir cin olduğunu, ayağının topal olması için cinin dua ettiği için bu hastalığa yakalandığını söyler. Sonra o cini çağırır, bir parmak boyunda, uzun külahlı, kırmızı pabuçlu adam gelir (Çobanoğlu, 2003: 116-118).

İkinci memorat Ali Akyıldız'dan derlenmiştir. Mehmet adında bir adam tarlada yemek yerken yemeğin yanında bir kurbağa görmüş. Kurbağa yemeğin içine girince kaşıkla kurbağaya vurmuş. O sırada adam baygınlık geçirmiş. Bir hocaya götürmüşler, o da "o tarlaya yüzünü bile dönme" demiş. Beş yıl bir şey 
olmayınca Mehmet tarlaya yine gitmiş ve orada baygınlık geçirmiş. Bunun üzerine yine hocaya gidilmiş. Hoca, o kurbağanın cinlerin reisi olduğunu, kurbağa ölürse Mehmet’i de öldüreceklerini, ölmezse Mehmet’i öldürmeyeceklerini söylemiş (Çobanoğlu, 2003: 119).

Cinlerin kurbağa şekline girmesi memoratı ile ilgili başka bir örneği Nemika Yeloğlu Kütahya'da derlemiştir. S.A.'dan derlenen memorata göre Trabzon'da yaşlı bir amca dere kenarında gördüğü bir kurbağayı tekmeler. Akşam olduğunda evine iki jandarma gelip onu kayalık bir yere götürürler. Mahkeme kurulur, davacı olarak ayağı kırık, başı gözü sargılı bir kadın gelir, adamdan şikâyetçi olur. Hâkim kadına “ ben sana insan ayağı altında dolaşma demedim mi? Götürün, idam edin” der. Adamı bırakırlar, ertesi gün gider bakarlar ki ağacın olduğu yerde bir kurbağa sallanıyordur (Yeloğlu, 2009: 560-561).

\section{Sonuc}

Halkbilim alanında yaklaşık 80 yıllık bir geçmişi olan memorat türünün Türkiye'deki geçmişi ise sadece 15 yıldır. Bundan dolayı memorat kavramına yönelik teorik ve saha derleme çalışmaları çok az sayıdadır. Ancak bu alışmaların giderek arttığı da gözlenen bir durumdur. Memorat türüne dair yeni bilgilerin elde edilmesi için tek kaynağı sözlü saha derlemeleri olmadığı ve olmayacağı da muhakkaktır. Bir yandan sözlü derlemeler devam ederken bir yanda da yazılı metinlerde memoratların izini sürmek mümkündür. Sadece modern metinler değil en baştan beri gerek edebî gerekse tarihî ve diğer metinlerde karşlaşılabilecek memorat örnekleriyle herhangi bir memorat tipinin tarih içinde nassl bir gelişim ve değişim gösterdiğini görmek mümkün olmaktadır.

Bu çalışmada ele alınan Bedâyiü'l-âsâr bağlamında cin memorat tiplerinin 400 yıldan fazla bir zaman diliminde pek fazla değişikliğe uğramadan günümüze kadar ulaştığı görülmüştür. Daha ayrıntılı olarak incelenen cinlerin kurbağa şekline girmesine örnek alınan dört memoratın benzer yapıda olduğu tespit edilmiştir. Başka metinler incelendiğinde başka memorat örneklerinin de çlkma ihtimali yüksektir. Böylece memorat tiplerinin tarih içindeki serüveni de daha kolay bir şekilde görülebilecektir.

\section{Kaynakça}

Beyaz, D. (2018). “Türk Halk Kültüründe Cinler”, Kocaeli Üniversitesi Sosyal Bilimler Enstitüsü Yüksek Lisans Tezi, Kocaeli.

Çobanoğlu, Ö. (2003). Türk Halk Kültüründe Memoratlar ve Halk İnançları, Akçağ Yayınları, Ankara.

Hallaç, A. T. (2018). "Memorat Kavramının Tanımlarındaki Belirsizlik ve Bir Tanım Denemesi" Akademik Dil ve Edebiyat Dergisi C: 2, S: 2, s. 181-211.

Sevindik, A.- Yaman, S. (2018). “Tokat’ta Öğrenci Yurtları Ekseninde Şekillenen Cin Memoratları ve Bunların Ortak Motifleri” I. Atlas Uluslararası Sosyal Bilimler Kongresi Kongre Tam Metin Kitabı, s. 387-394.

Ünlü, O. (2009). Cinânî, Bedâyiü’l-âsâr, Part I, Harvard University, Harvard, s. 27-57.

Ünlü, O. (2017). "Mensur Hikâyelerin Giriş Bölümlerinin Üslûbu Üzerine Değerlendirmeler" Klasik Edebiyatımızın Dili (Bildiriler), Atatürk Kültür Merkezi Başkanlığı, Ankara, s. 261-272.

Yeloğlu, N. (2009). "Kütahya ve Çevresinde Memorat Tasarımı", Dumlupınar Üniversitesi Sosyal Bilimler Enstitüsü Yüksek Lisans Tezi, Kütahya. 


\section{EK}

\section{Hikâyelerin Özetleri5}

16. Bursa'nın Muradiye semtinde oturan Hacı Murat anlatır: Komşusu ve mahalle müezzini olan Hacı Ahmet ile Muradiye hamamına gitmek üzere sözleşirler. Gece olunca Hacı Ahmet, Hacı Murat'ın evine gelir. Beraber yola çıkarlar. Yolda Ahmet'in boyunun bazen minare kadar uzadığını bazen de bir karış kadar küçüldüğünü görür. Hacı Murat bunu içtiği esrara yorarak yola devam ederler. Hamama girdiklerinde tellak Mahmut'a olayı anlatır. Tellak da uzayınca Hacı Murat hamamdan kaçarak uzaklaşır. Yolda caminin fenercisini görür. Başına gelenleri ona da anlatır. O anda fenerci uzayarak oradaki ağacın tepesine oturur. Hacı Murat oradan uzaklaşarak cami minaresinin yanındaki dükkanına gelir. Dükkanın önünde ortağı olan Bekir’i görür. Olayları ortağına da anlatır. Ortağı uzayıp minarenin şerefesine oturunca dayanamayıp düşer ve bayılır. Sabaha kadar orada baygın olarak kalır.

17. Bursa'da büyük caminin müezzini Karakaş anlatır: O zamanlarda cin bağlayabilen Enverî adında bir âlim ortaya çıkar. Karakaş da onun has öğrencisi olur. Bir gün Karakaş, Enverînnin eşinin hamama gittiği bir zamanda evine gider, evde çok güzel bir kadın görür. Onu Enverînnin annesi sanarak elini öper. Daha sonra hocasına, evde gördüğü kadının kim olduğunu sorar. Enverî de onun insan olmadığını, cin ülkesi padişahının kızı olduğunu söyler. Onu bağlamak için on yıl uğraştı̆̆ını, bu arada kızın ağabeyinin kendisinden haberdar olduğunu anlatır. Enverî̀yi öldürmek için yemin ettiğini ve daha fazla yaşamayı beklemediğini ifade eder.

18. Bir sipahi Trabzon yakınlarındaki Timarum'dan şehre gider. Akşama yakın geri dönmeye niyetlenir. Ancak biraz geç kalır ve yolda giderken hava kararır. Deniz kenarından giderken uzakta beyaz bir bina görür. Ona yaklaşınca bir direğe benzetir. Biraz daha yaklaşınca beyaz bir taşa benzetir. Yanına gelince bunun bir köpek yavrusu olduğunu görür. Sipahi daha sonra yoluna devam ederken birden bire atı durur ve hiç hareket etmez. Sipahi de atını denizin içinden götürür. Birden ormanın içinde minare uzunluğunda, insana benzeyen bir şahıs görür. Gelip sipahinin yanından yürümeye başlar, bir iken üç olurlar. Köye gelinceye kadar bu şekilde yürümeye devam ederler. Köye vardıklarında kaybolurlar. Sipahi evine girer ve iki ay boyunca yatağından kalkamaz.

19. Bursa'dan Hasan Dede gençliğinde, bir gün arkadaşları ile kırlara gezmeye gider. Dönüşte Hasan Dede bir büyük kurbağa görür ve ona taş atar. O gece uyurken iki kişi gelip onu uyandırırlar. "Bugün taş attığın, kurbağa değil bir cindi. Bu yüzden onun gözünü çıkarttın, gözünü yalarsan iyileşir” diye ondan rica ederler. Hasan Dede yaralı cini görünce ondan tiksinir ve "yalamam" der. Cinler yalvarır fakat Dede inat eder. Bunun üzerine cinler Hasan Dede’nin üzerine aslan ve ejderha gönderirler. Hasan Dede âyete'l-kürsî okuyarak onları def eder. Sonra sırasıyla Hasan Dede'nin hocasını, iki güzel cariyeyi ve iki güzel oğlanı gönderirler. Hasan Dede her seferinde âyete'l-kürsî okuyarak onlardan kurtulur. Cinler istediklerini yaptırmayınca evini ateşe verirler, olmayınca sel gönderirler ve ev su içinde kalır. Sonunda dayanamayan Hasan Dede bayılır. Ertesi gün hocasına gider ve akşam başından geçenleri bir bir anlatır. Hocası da onu tebrik eder ve cinlerden korunması için bir dua yazıp eline verir. Akşam olduğunca cinler yine gelirler. Ancak duanın etkisiyle eve giremezler ve dışarıdan eve taş atıp evin damına çıkarlar. Daha sonraki günlerde ise hiç gelmezler. Hasan Dede ise hayvanlara taş atmamaya yemin eder.

20. Daha önce Kütahya'da oturan Firâkî, bir gece evinde uyurken kulağına bir çalgı sesi gelir. Kalkıp bahçeye iner. Bahçeye büyük bir eğlence meclisinin kurulmuş olduğunu görür. Dayanamayıp bu

5 Eserin tamamının geniş bir özeti için bkz. (Ünlü, 2009: 27-57). 
meclisin içine girer. Güzel bir delikanlı yanına gelir, onun elini öpüp meclisin baş köşesine buyur eder. Yenilip içildikten sonra sabaha karşı meclis dağılır. Ertesi gece yine o delikanlı gelip Firâkîyi uyandırarak birlikte sabaha kadar sohbet ederler. Bundan sonra hemen her gün görüşüp sohbet etmeye devam ederler. Bir gece delikanlı Firâkî̀ye üçbin akçe verip pazarda satılacak bir atı almasını ister. Firâkî de gencin dediklerini yapıp atı satın alır. Sonraki her sabah atının ayağının yanında beş akçe bulur. Yine bir gece genç, Firâkî̀ye elli bin akçe verip pazarda satılacak olan bir cariyeyi almasını ister. Firâkî de gencin dediklerini yapar. Firâkî̀nin bu olaylardan sonra çok malı olur, zihni açılır, çevresinde bilgin birisi haline gelir ve sonra İstanbul'a taşınır. Bir gece o delikanlı Firâkî̀nin yanına gelir. Kâfir olan cinlerle savaşa gittiklerini, belki hiç görüşemeyeceklerini söyler, dua etmesini isteyerek vedalaşır. Bundan sonra Firâkî günlerce delikanlıdan merakla haber bekler. Bir gece, kaldığı yerde bir matem sesi duyar. Yanına siyahlar içinde üç kadın gelerek delikanlının şehit olduğunu söylerler. Firâkî’yi yanlarına alıp Yedikule taraflarında bir yere götürürler. Firâkî burada bir miktar Kur'an okur. Delikanlının babası "oğlumuza hep dua et" diye vedalaştıktan sonra oradakiler birden kaybolurlar.

25. Arkadaşlardan birisi Nevrekop’ta bir süre kadılık yapar. Bir gün birisi "filan mahallede oturan bir eskicinin evinin damına cinler taş atarlarmış" diye haber verir. Birkaç gün sonra eskicinin kadıya bir işi düşer. Kadı ona olayın doğruluğunu sorar. Eskici de olayı doğrular fakat cinlerin neden taş attıklarını bilmediğini söyler. Bu olay şehrin beyinin de kulağına gider. Bir gün eskicinin komşuları beye cinlerin kendi evlerine de taş atmaya başladıklarını ve eskiciden şikayetçi olduklarını söylerler. Bey de kadıyı yanına alarak eskicinin evine gider. Eskicinin evinde otururken cinler eve taş atmaya başlarlar. Kadı, cinlerle konuşmak ister fakat cinler kadıyla alay ederler. Kadı kızıp onları yok edeceğini söyleyince cinlerden biri konuşmaya başlar. Bu cinlerin Cemşid adında genç bir padişahları varmış. Bu padişah dolaşırken gördüğü eskicinin bahçesini çok beğenmiş ve orada oyalanıp eğlenmeye başlamış. Fakat eskiciyi orada istemediği için evini taşlamaya başlamış. Eskici evinden çıkmayınca bu sefer komşularının evlerini de taşlamaya başlamışlar. Bunun üzerine kadı eskiciye evini satıp başka bir yere gitmesi gerektiğini tavsiye eder. Eskici de başka bir yere gider. Kadı daha sonra duyar ki, cinler eskiciye orada da musallat olmuşlar evini yine taşlamaya başlamışlar.

26. Ankara'da Karaoğlan çarşısını bir cin kızı tutmuş. Birçok insan onu görmüş hatta onunla konuşanlar bile varmış. Bir imam, bir gece sarhoş bir şekilde oradan geçerken cin kızını uzaktan görmüş. Ertesi gece yine sarhoş bir şekilde Karaoğlan çarşısına gelir. Türkü söyleyerek yürürken kız gelir, önünde durup dans etmeye başlar. Bu sırada kızın elbisesindeki süslü pullardan biri yere düsser. İmam da onu eline alınca kız ona "sakın elindekini kaybetme yoksa seni yok ederim" der. Ertesi sabah imam uyandığında elindekinin bir çam kabuğu olduğunu görür. O gece elindekini kıza vermek ister ama kız almaz. Daha sonra sık sık çarşıya gelerek kızla görüşmeye başlar. Bir gün kıza bir kuzu kebabı götürür. Kız bu yemeği beğenmeyip "biz et yemeyiz sen bana eti kemirilmiş bir kemik parçası getir" der. Birkaç gün sonra olayı duyan imamın babası cinle görüşmemesi için onu uyarır. İmam da o günden sonra Karaoğlan çarşısına hiç uğramaz.

28. Eski zamanlarda Ahmim şehrinde iki kardeşin şehir dışında üzüm bağları varmış. İki kardeş bu bağı beklerken yiyecek ekmekleri bitmiş. Kardeşlerden birisi ekmek almak için köye gider. Dönüşü biraz geciktiği için yolda hava kararır. Yolda yürürken bir köpek yavrusu görür. Bağı bekler düşüncesiyle boğazına bir ip bağlayıp yanında götürmeye başlar. Bir süre sonra köpek yavrusunun kocaman bir çoban köpeğine dönüştüğünü görür. Daha sonra bir çocuğa dönüşür. Adam ayete'l-kürsi okumaya başlayınca çocuk ona yaklaşamaz. Yoldan çıkarak bir tarlanın içinden yürümeye başlar. Karşıdan kardeşinin geldiğini görünce sevinir. Başından geçenleri ona anlatırken kardeşinin boyu uzayarak minare kadar 
olur. Okumaya başlar, kardeşi buharlaşıp kaybolur. Güçlükle eve gelir. Ertesi sabah kardeşi onu şehirde bir hekime götürür, dört ay boyunca yatağından kalkamaz.

48. Molla Gürânî evladından biri İstanbul'dan bir gemiye binip yola çıkar. Yolda, ayağının birinin dizinden aşağısı olmayan birisiyle tanışır. Sohbet arasında ayağının neden olmadığı konusu açılınca adam anlatmaya başlar: Bir zamanlar çok güzel yüzlü bir delikanlıdır. Her gün âşıkları etrafında dolaşırlar, onu görmeden edemezler. Bir sabah kalktığında ayağına alaca bir yılanın sarılmış olduğunu görür. Delikanlının uyandığını görünce yılan çözülüp gider. Olayı babasına anlatır. O da oğlunu yılandan korumak için evin içinde ve damda yatırır. Ama her defasında yılanı ayağına sarılmış şekilde bulurlar. Yllan delikanlıya zarar vermediği için durumu kabullenirler. Bir yıl sonra delikanlının asker olan amcası şehre döner. Sohbet sırasında bu olaydan bahsederler. Amcası buna çok kızar ve yılanı öldürmeye karar verir. Oradakiler amcasını engellemeye çalışsalar da başaramazlar. Amcası yılanı elindeki küçük baltayla yaralar, o sırada yılan kaybolur. Delikanlı o akşam uyurken rüyasında uzun boylu bir yiğit gelir. Ona "sen beni bir zalime öldürtmek istedin ben de seni sağ bırakmam" der. Ayağına bir öpücük kondurduktan sonra kaybolur. Sabah olunca delikanlının ayağı ağrımaya başlar. Gün geçtikçe ağrılar artmaya başlar. Hekime giderler o da ayağının kesilmesi gerektiği yoksa öleceğini söyler. Çaresiz kabul ederler ve ayağını dizinden alt tarafından keserler.

53. Eski zamanlarda Kefe'de Başmakçı Hasan adında bir ayakkabıcı varmış. İşinin ehli olan bu ayakkabıcı kazandığı parayla şarap alır içermiş. Bir gün parası bitince Kefe'den ayrılır ve Mısır'da Kahire'de bir hana gelir. Fakat hancı, handa yer olmadığını söyler. Hasan yalvarınca hancı "bir oda vardır, ancak orada yatanı sabah ölü buluruz" der. Hasan yine de o odada kalmayı kabul eder ve odaya yerleşir. Gece yarısı olunca "varayım mı" diye bir ses duyar. Fakat o ilgilenmez ve üç defa bu söz tekrarlanır. Sonunda dayanamayıp "geleceksen gel” der. Kapıda çok güzel bir kız görür. Kız, şimdiye kadar kimsenin kendisine cevap vermediğini, hepsinin de korkudan öldüğünü söyler. O günden sonra her gece sabaha kadar sohbet etmeye başlarlar. Mısır'da yılan çok olduğu için bazen yılanlar evlere de girerlermiş. Bu yılanları evden çıkarmayı meslek edinmiş olan insanlar da varmış. Bir gün Hasan ile kız sohbet ederlerken bunlardan birisinin geçtiğini görünce kız "acaba yılanları nasıl çıkarıyorlar" diye meraklanmış. Daha sonra kız yılan şekline girer ve yılancıyı çağırırlar. Adam gelip elindeki düdüğü üç defa çalar. En sonunda yılan girdiği delikten çıkar. Yılancı gittikten sonra kız tekrar insan şekline girer. Fakat kız yılancının düdüğünün sesi yüzünden hasta olur. Hasan'a "eğer ben ölürsem diğer cinler seni sağ bırakmazlar. Eğer bir gece feryat duyarsan ben ölmüşümdür ve hemen o an bu odayı terk et" der. Aradan birkaç gün geçtikten sonra Hasan feryat ve matem sesleri duyar. Hemen eşyalarını toplayıp odayı ve Kahire'yi terk edip Kefe'ye geri döner. Ölünceye kadar da orada kalır.

54. Bursa Sultan Murad Camii müezzini Kadri anlatır: Bir gün bir arkadaşla gezerken bir mecnuna rast gelirler. O mecnun da başından geçenleri onlara anlatır. Gençliğinde bir kız sevdiğini ve firsat buldukça buluştuklarını anlatır. Bir gece yatağında yatarken yanında birisinin varlığını hisseder. Bakar ki sevdiği kız yanında yatıyor. Sefasıyla meşgul olur ve sonra uyumaya başlar. Uyandığında kızın yanında olmadığını görür. Ertesi gece de aynı şekilde kız gelir. Üçüncü gün kızı dışarıda görünce "gece yarısı evden nasıl çıkabildiğini” sorar. Kız da "ben gündüz bile zor dışarı çıkıyorum. Sana cin uğramıştı»" der. Akşam olup kız yanına geldiğinde ona durumu sorar. Kız da "ben cin padişahının kızıyım. Bundan sonra benden başkasına bakarsan seni öldürürüm” der. İki üç yıl boyunca bu şekilde devam eder. Sonra adamın aklı yavaş yavaş gitmeye başlar. Zaman zaman kendisini yüksek yerlerde atmaya çalışır. Sonunda bir cinci hoca getirirler. O da bazı işlemler yaparak adamı cinin elinden kurtarır. 
57. Arkadaşlardan birisi anlatır: Bir zamanlar Bursa'da Peri Paşa Hamamını tutup orda kalmaktadır. O zamanlar sürekli olarak şarap içmektedir. Bir gece yine hamamda uyurken birisinin kendisine seslendiğini duyar. Kalkınca hamamda 12-13 kişinin olduğunu görür. Onlardan birisi hamamın kurnasını açmasını ister. Dediklerini yapar ve yerine döner. Bu sırada çok korkmuştur. Daha sonra adamlar gelir, işlerinin bittiğini ve kurnayı kapatmasını isterler. Bir tasa da bir miktar para bıraktıklarını söylerler. Ertesi günü bir arkadaşıyla beraber hamamda kalırlar. Ama cinler arkadaşına çok sıkıntı verirler. Sonunda hamamı başkasına kiralar, cinlerin baskısından da kurtulur.

A.17. Arnavut vilayetinde Dıraç kalesinde ağır hasta olanların bedenine daha önceden ölmüş olanların ruhları girermiş. Ruh o hastanın diliyle konuşur ve kendi hallerinden haber verirlermiş. Kendilerine dua edilmesini isterlermiş. Etraftakiler hastanın dinine göre başında İncil veya Kur'an okurlarmış.

A.18. Çivizâde'nin öğrencilerinden Mevlana Halil, Mısır'da iken bir eve çağırılır. Gittiğinde o evin cariyesinin bedenine bir cin girdiğini söylerler. Bu cini çıkarmak için bir büyücü getirilir. Fakat cin Farsça konuştuğu için ne dediği anlaşılmamaktadır. Mevlana Halil cinin dediklerini oradakilere tercüme eder. Birkaç işlem yapıldıktan sonra cin dayanamayıp çıkar. Bu gibi olaylar çoktur. Hatta, bu çeşit ölüleri göbeklerinden yere mıhlarlar veya başını kesmek, yine gitmezse ateşe vermek caizdir diye Ebussuud Efendi'nin fetvası vardır.

A.19. Mora'da bir gün bir adam ölür. Aradan üç dört ay geçtikten sonra adamın evindeki hizmetçisi, efendisinin gelip kendisiyle ilişkiye girdiğini söyler, fakat kimse ona inanmaz. Daha sonra Pîrî Efendi adlı bir âlimden yardım isterler. Kadın evde onlar dışarıda beklerler. Hizmetçi efendisi geldiğinde dışarıdakilere haber verir. Eve girdiklerinde adamı hizmetçisinin üzerinde görürler. Cin, gelenleri görünce kaybolup gider. Kadın da bir süre sonra ölür.

A.20. Sandıklı yakınlarında Gölcük yaylasında yörüklerden bir kızın sağ uyluğuna bir cin yerleşir. Oradaki memurlardan birine de Gediz kenarında değirmen yapma emri verilmiştir. O kızın da olduğu bir yerde kendi kendine "acaba kaç değirmen yapılı" diye düşünürken kızın bedenindeki cin "beş, beş" diye ona cevap verir. O tarafların halkı niyetlerinin olup olmayacağını ona söyletirlermiş. Kız hiç konuşmaz, hep cin konuşurmuş. 